\title{
APRESENTAÇÃO COMENTADA: "TERRITÓRIOS DA INFÂNCIA"
}

emos em mãos mais um número dos Cadernos Cedes, sempre voltados à formação docente e agora com uma dose de ineditismo: destinado a docentes que trabalham com infância e histórias.

Sem didatizar a literatura infantil, as sete autoras, todas mulheres e professoras, uma italiana, uma portuguesa e as outras cinco brasileiras, escrevem sobre personagens infantis na produção cultural para crianças, desvendando características de seus autores, do momento histórico e contexto em que foram produzidas. Com bibliografia científica, problematizam as circunstâncias de criação e de disseminação das fantásticas histórias, estabelecendo interlocução entre a produção cultural para crianças, a análise crítica das personagens destacadas e os rigores da pesquisa científica.

O presente Caderno anuncia mais um território da infância pouco explorado na formação docente: as histórias nos livros e na mídia. Ainda que este recurso faça parte da programação curricular nacional das séries iniciais do ensino fundamental, assim como da primeira etapa da educação básica: a educação infantil em creches e pré-escolas. Portanto, definir critérios para selecioná-las e contá-las às crianças e/ou propor-lhes a leitura ou a sua audiência, com o intuito exclusivo de proporcionar o prazer de imaginar e o livre pensar, representa uma dimensão também pouco explorada nos currículos para a faixa etária da infância, estabelecida pelo Estatuto da Criança e do Adolescente (ECA) como sendo de 0 a 12 anos de idade.

As personagens infantis aqui refletidas são Harry Porter, Narizinho, Pippi Meialonga, Momo, Eloíse, Grimble, os três porquinhos, Dragonball $\mathrm{Z}$ e as meninas superpoderosas. $\mathrm{E}$ temos também uma personagem especial, não infantil, que, se fosse viva, estaria fazendo cem anos: Astrid 
Lindgren, criadora de Pippi Meialonga, num texto em que a professora italiana da Universidade de Bolonha a homenageia.

Ao anunciar mais este território da infância para contribuir na formação docente, este número dos Cadernos Cedes mostra o quanto é profícuo e acaba deixando um gosto de quero mais. O que diz a bibliografia poética? Quem está lendo essas personagens no Brasil e no mundo? As bibliotecas das escolas públicas brasileiras oferecem estas personagens para divertirem e provocarem a imaginação da criançada? E as artes, o que têm a nos dizer? A poesia? A literatura? $\mathrm{O}$ cinema? $\mathrm{O}$ teatro? A fotografia?

Ana Lúcia Goulart de Faria Doutora em Educação e professora da Faculdade de Educação da Universidade Estadual de Campinas (Unicamp) 